\title{
CONSIDERAÇÕES SOBRE O DIREITO DAS COISAS NO NOVO CÓDIGO CIVIL
}

Adauto de Almeida Tomaszewski"

SUMÁRIO: 1. Introdução e Escorço histórico. 2. As mudanças impostas pela evoluçâo. 3. Uma análise crítica acerca do Dircito das Coisas no novo Código Civil. 4. Conclusão. 5. Bibliografia.

SUMMARY: 1. Introduction and Historic. 2. The Imposed Changes by the Evolution. 3. An Analysis Critic about the Right of the Things in the New Civil Code. 4. Conclusion. 5. Bibliography.

SUMARIO: 1. Introducción e Histórico. 2. Los Cambios Impuestos por la Evolución. 3. Una Análisis Crítica del Derecho de las Cosas en el Código Civil Nuevo.4. Conclusión. 5. Bibliografia.

RESUMO: Anotações sobre a questão da posse e propriedade no novo Código Civil e a sua função social. Breves considerações sobre a evolução do direito de propriedade e algumas reflexóes críticas sobre determinadas normas polèmicas e sua difícil interpretação. As propostas de alteração do Código.

ABSTRACT: Annotations about the subject of the ownership and property in the new Civil Code and its social function. Brief considerations about the evolution of property right and some critical reflections on certain polemic norms and their difficult interpretation. Proposals of alterations of the Code. 
RESUMEN: Anotaciones sobre el tema de la propiedad y de la característica en el nuevo código civil y su función social. Breve consideraciones sobre la evolución de lo derecho de la propiedad y de algunas reflexiones críticas en ciertas normas polémicas y su interpretación difícil. Las sugestiones de alteraciones del Código.

PALAVRAS-CHAVE: Histónico. Posse. Propriedade. Função Social. Desapropriação. Alterações.

KEY-WORDS: Historical. Ownership. Property. Social function. Dispossession. Alterations.

PALABRAS-LLAVES: Histórico. Ownership. Property. Social function. Dispossession. Alteraciones.

\section{Introdução e Escorço histórico}

Se nos voltarmos ao mais distante passado do homem neste planeta, será possivel perceber que a fome representava uma necessidade a ser satisfeita e por conseguinte, obrigava homens e animais à procura de elementos necessários à subsistência, apossando-se de tudo quanto the fosse possível para tanto. Talvez esta tenha sido a primeira manifestação da relação do homem com as coisas que, naquela época, ainda não eram bens juridicamente tutelados.

A noção de propriedade partiu então da posse daquilo que era necessário e útil à saciedade da fome que se tornava cada vez mais representativa, pois era necessário, em muitos casos, promover razoável armazenamento, decorrência imediata de um esforço do homem.

Assim, os alimentos são as primeiras coisas apropriadas pelos homens, por fome, agrado ou para se abastecer nos momentos de infortúnio. Além da propriedade dos alimentos, sabemos que o homem portava vestes, instrumentos ou utensílios, ou, depois no avançar do tempo, ao estabelecer-se e abandonar o nomadismo, grosseiros instrumentos de utilização na lavoura ou cultivo.

Desta forma, o direito de propriedade aparece rudimentarmente sobre coisas móveis: coisas apreendidas na natureza e bens trabalhados pelo homem para servir-lhe de utilidade.

Movido por este ânimo, surgiu a propriedade sobre animais inferiores, 
úteis e próprios à satisfação de suas vicissitudes. Começou então o homem a criar rebanhos, domesticar animais, o que acabou exigindo sua atenção para as terras de pastagem; cuidava então das terras férteis com um instinto próprio de conservação.

Todavia, se de início a ocupação era pacífica, após um período de tempo surgiram conflitos entre diferentes grupos e os mais fracos cederam ou sucumbiram ante a lei do mais forte.

Por este motivo, algumas áreas de cultivo ou pastagens foram possuídas de uma forma comum e inalienável. Entretanto, por muito tempo, apesar das lutas entre grupos, a propriedade continuou comum.

Mesmo que esta seja uma breve incursão no passado, não se pode deixar de fazer menção à civilização egípcia, pois aquele povo, dada a sua cultura, acreditava que todas as terras e o que delas se extraísse pertencia à divindade, sendo o faraó o "representante vivo daquele 'Deus'". Por este, entre outros motivos, laboravam a terra e entregavam todo o produto ao seu chefe supremo, que lhes devolvia uma parte em forma de "ração", que ele acreditava ser bastante suficiente para a subsistência de seu povo.

Quanto aos Cristãos, inicialmente estes não conheciam a propriedade individual. TERTULIANO à sua época dizia: tudo é comum entre nós, exceto as mulheres. SAO JUSTINO acrescentava: trazemos e dividimos tudo. Lembremo-nos que CRISTO, ao dividir o pão, pregava que as posses e propriedades não nos pertenciam, senão ao "Pai".

Em verdade, acredita-se que a propriedade individual começou a surgir mais propriamente a partir da especialização da família nas sociedades humanas. Por este motivo, a subsistência obtida por meio da cultura de uma parcela do solo por um membro da sociedade, implicava em reinvindicação e reconhecimento de um trabalho e direitos análogos a todos os outros membros da tribo.

Conforme anteriormente dito, a propriedade na idade primitiva era da colheita e não das terras cultivadas e mesmo na Grécia Antiga, a base era a crença ou a religião. A família estava ligada ao fogo, que por sua vez estava ligado ao solo: ou seja, "Deus da família queria uma morada fixa". Segundo os gregos, foi o fogo que ensinou o homem a construir suas casas. Decorrente deste estado de coisas, foi a religião que primeiramente garantiu o direito de propriedade. Ressalte-se que na Grécia, antes da propriedade individual, praticou-se a propriedade comum ou coletiva. Somente a título de ilustração, Sparta tinha um vasto domínio de florestas e montanhas, mas por muito tempo foi proibido vender o solo e fazer testamento. 
No Direito romano, a especialização da propriedade privada foi conseqüência do progresso, pois em seu princípio, esta também era comum; o ager publicus e a mancipatio demonstram que somente coisas móveis eram objeto de alienação. Isto é fácil de perceber, pois antes do advento da Lex Poetelia Papiria, no século IV antes de Cristo, o corpo do devedor é que respondia por suas dívidas. Àquela época, o direito de propriedade se aplicava aos escravos, animais e objetos mobiliários, ou o que exclusivamente a mão podia tocar e apreender.

A religião doméstica contribuiu mais do que as leis para a individualização da propriedade. A comunidade da aldeia foi o fundamento da propriedade rural. Este grupo social se fragmentou em comunidades consangüíneas, as gentes do Direito romano, oportunizando que se estabelecesse, em uma noção inicial, o Direito de sucessão, pois o herdeiro apenas continuava a pessoa do defunto, em honra deste, na subserviência aos "deuses" e manutenção do sepulcro da família.

Depois de algum tempo é que no Direito romano a propriedade passou do jus gentium para o jus civile, estabelecendo do DOMINIUM QUIRITARIUM, pelo quê a propriedade somente era adquirida pelos homens que podiam comerciar. Somente sob o império de Justinianus é que o comércio foi aberto a todos os homens livres.

Por sua vez, os germanos que eram inconstantes e belicosos deram origem aos feudos, inicialmente concedidos de forma temporária ou vitalícia por serviços militares prestados.

Com um pouco de avanço no tempo, os feudos passaram a ser perpétuos e indivisíveis. O feudalismo absorveu por completo a noção de propriedade e, somente no século XVIII, os camponeses começaram a adquirir alguns terrenos.

O Código Civil francês afirmou categoricamente a propriedade privada: Napoleão disse que, mesmo com seu poder, não poderia violar a menor propriedade dos particulares, sob pena de prejudicar a estabilidade das instituições. Por este motivo, somente por razões de utilidade pública, com. prévia e justa indenização alcançar-se-ia a propriedade privada. Aliás, este Código ainda foi mais longe e acabou com algumas figuras que impropriamente mostravam resquícios do feudalismo, como os fideicomissos e a enfiteuse.

Posteriores Códigos não o acompanharam e, por exemplo, já àquela época, na Inglaterra, foi explicitado que todas as terras pertenciam à Coroa. No Direito Russo, naquele período ainda havia a comunhão das terras nos municípios rurais. 


\section{As mudanças impostas pela evolução}

Como o mundo mudou, evoluiu, os efeitos foram facilmente percebidos. Mesmo na vigência do nosso antigo Código Civil, a propriedade foi sendo limitada por todos os lados. Isto foi identificável nos momentos em que o proprietário deveria pedir autorização ou submeter-se a uma eventual interdição.

Diante do interesse público, desaparecia a propriedade particular, motivo pelo qual surgiram regulamentos sobre domínio das fontes, das minas, do espaço aéreo, etc... . Tudo explicado pelo simples fato de que todo indivíduo deve cumprir uma dada função na sociedade, na razão direta do lugar que ocupa como detentor de riqueza. E porque detém tal riqueza, pode cumprir tal tarefa, pois somente ele pode aumentar a riqueza geral, fazendo valer o capital que detém. Decorrente desta noção, a propriedade já não é mais um direito subjetivo do proprietário, mas a função social do detentor da riqueza, como afirmaram LANDRY, MAURICE HAURIOU e LEON DUGUIT ao longo de suas excelentes obras.

A evolução da propriedade privada depois da Revolução Francesa não a eximiu de críticas e combates. SANTO AGOSTINHO afirmou que era do Direito humano, näo do Divino, que o homem guardasse o que possuía, pois o barro que fez os pobres e ricos era o mesmo.

Inegavelmente, a propriedade já é um sentimento humano, faz parte de nossa mentalidade; na tábua de Moisés já continha o preceito de não tomar para si o que é do próximo.

Com a natural evolução, o homem começou a produzir mais do que consumia, acumular riquezas e as leis assim o garantiam, nos códigos e nas mentalidades. A partir do momento em que o homem crê ter este direito e que a Lei o protege, ele volta-se contra todos $\mathrm{cm}$ busca desta proteção.

Foi inclusive com base nesta evolução que o novo Código, mais precisamente no DIREITO DAS COISAS, trouxe uma certa modernidade em relação ao antigo, até mesmo por efeito reflexo da vigente Constituição Federal. A partir de então, o direito real é visto em razão do novo conceito de propriedade, com base no princípio constitucional de que a função da propriedade é social, superando-se aquela antiga compreensão romana quiritária, decorrente do interesse exclusivo do individuo, do proprietário ou do possuidor. 


\section{Uma análise crítica acerca do Direito das Coisas no novo Código Civil}

O novo Código Civil, no Livro III trata do DIREITO DAS COISAS, sendo inclusive motivo de críticas por parte de renomados autores, pois as coisas denotam apenas uma das espécies de bens da vida. Aliás o legislador não uniformizou o seu trabalho e somente a título de exemplo, percebemos que no artigo 1.197, ele utilizou-se da expressão coisa em seu poder, no parágrafo único do 1.198, valeu-se do termo em relação ao bem e no artigo 1.199, encontramos coisa indivisa, entre tantas outras hipóteses.

Este Livro do novo Código Civil perpetua uma observação da doutrina que já dura muito tempo acerca da distinção entre coisas e bens. Esta advertência já era presente no antigo Código, iniciando-se já na Parte Geral ao tratar das diferentes classes de bens. O pranteado Washington de Barros Monteiro já explicava que existem coisas que não são bens, pois não são suscetíveis de apreciação econômica. Penso que esta discussão acerca da nomenclatura já é algo consolidado e muitas coisas mencionadas nesta parte do Código não atendem necessariamente àquela distinção entre COISAS e BENS e nem por isso deixam de receber a tutela jurídica. Um bom exemplo disto é a regra constante do artigo 1.228, Parágrafo Primeiro, que apresenta um rol de bens de toda a sociedade, como a flora, a fauna, as belezas naturais, o equilíbrio ecológico e o patrimônio histórico e artístico, bem como a tentativa de se preservar da poluição a água e o ar.

Não destoando da sistemática adotada por Beviláqua, o novo Código Civil também inicia as considerações com a posse e a sua classificação. É sabido que a POSSE é um instituto complexo e recheado de controvérsias e conflitos, desde a época de Savigny e Ihering, com todas aquelas discussões teóricas acerca de sua natureza jurídica. Mas isto não é sem motivo: a partir do instante em que a propriedade e a posse se separam, este contraste se revela. Ademais, surge muito mais quando o proprietário é separado clandestina ou violentamente da sua coisa, de maneira que vemos um proprietário que não possui e um possuidor que não é proprietário.

Consoante se depreende da leitura do artigo $1196,{ }^{1}$ o novo Código aproxima-se mais da concepção de Thering do que o ora revogado.

\footnotetext{
${ }^{1}$ Art. 1196. Considera-se possuidor todo aquele que tem de fato o exercício, pleno ou não, de algum dos poderes inerentes à propriedade.
} 
Acerca dos modos de aquisição, o legislador do novo Código também atendeu os reclames da doutrina e não especificou um rol, pois se a posse é um estado fático, não havia necessidade de enumerar as formas de se adquirita. Portanto, merece elogios a redação do artigo $1.204^{2}$. Todavia, o $1.205^{3}$ não tem o menor cabimento, já que seu conteúdo é totalmente dispensável e a gestão de negócios já fora tratada em momento anterior.

Uma outra nota de elogio é no que se refere ao artigo 1.210, Parágrafo $2^{2}$, ao excluir a exceção de domínio nas ações possessórias. Ressalta-se que este é um fato que encontramos muito facilmente no novo Código: disposições acerca de matéria processual. Desta maneira, o réu apenas apresentará resposta versando sobre o problema possessório. É bem verdade que, no antigo Código Civil, o capítulo que tratava da Proteção Possessória não estava em localização adequada, mas como em 1916 não se tinha um Processo Civil muito claro, era algo até justificável. Agora não mais seria necessário mesmo.

Sempre foi pacífico que tanto as idéias de Ihering como de Savigny permeavam o antigo Código: as antigas disposiçóes sobre a perda da posse deixavam transparecer a perfilhação deste último autor. $\mathrm{O}$ atual Código mais uma vez aproxima-se do Código Civil Alemão, que a este respeito tem forte influência de Thering e, no artigo $1.223^{4}$, apresenta apenas uma regra geral acerca da perda da posse.

Mas, até aqui discorri sobre situações pacíficas e de fácil deslinde. Dificil é tratar, entre outras coisas, do artigo 1.228:

Art. 1.228. O proprietário tem a faculdade de usar, gozar e dispor da coisa, e o direito de reavê-la do poder de quem injustamente a possua ou detenha.

$\S 1^{\circ} \mathrm{O}$ direito de propriedade deve ser exercido em consonância com as suas finalidades econômicas e sociais e de modo que sejam preservados, de conformidade com o estabelecido em lei especial, a flora, a fauna, as belezas naturais, o equilíbrio ccológico e o patrimônio histórico e artístico, bem como evitada a poluição do ar e das águas.

$\$ 2^{\circ}$ São defesos os atos que não trazem ao proprietário qualquer comodidade, ou utilidade, e sejam animados pela intenção de prejudicar outrem.

$\$ 3^{\circ}$ O proprietário pode ser privado da coisa, nos casos de desapropriaçăo,

\footnotetext{
2Art. 1.204. Adquire-se a posse desde o momento em que se torna possível o exercício, em nome próprio, de qualquer dos poderes inerentes à propriedade.

Art. 1.205. A posse pode ser adquirida:

I - pela própria pessoa que a pretende ou por seu representante;

II - por terceiro sem mandato, dependendo de ratificação.

${ }^{4}$ Art 1.223. Perde-se a posse quando cessa, embora contra a vontade do possuidor, o poder sobre o bem, ao qual se refere o art. 1.196.
} 
por necessidade ou utilidade pública ou interesse social, bem como no de requisição, em caso de perigo público iminente.

$\S 4$ o O proprietário também pode ser privado da coisa se o imóvel reivindicado consistir em extensa área, na posse ininterrupta e de boa-fé, por mais de cinco anos, de considerável número de pessoas, e estas nela houverem realizado, em conjunto ou separadamente, obras e serviços considerados pelo juiz de interesse social e econômico relevante.

$\S 5^{\circ}$ No caso do parágrafo antecedente, o juiz fixará a justa indenização devida ao proprietário; pago o preço, valerá a sentença como título para o registro do imóvel em nome dos possuidores.

É possível alinhar as seguintes considerações: o "caput" dá a medida dos poderes do proprietário; o parágrafo $1^{\prime}$ demonstra a preocupação com a função social e a proteção ao ambiente sadio, e o parágrafo $2^{3}$ condena o abuso de direito, o espírito emulativo.

Com relação aos parágrafos $4^{2}$ e $5^{2}$, se de um lado afirma-se que a Usucapião ganhou contornos importantes, ao absorver as formas do extraordinário e constitucional, apresentando-nos o legislador um novo tipo de usucapião, de outro, doutrinadores de nomeada são enfáticos em afirmar da inconstitucionalidade, inconveniência e dificuldade de implementação destas disposições.

Em primeiro lugar diz-se que não poderia a lei ordinária estabelecer mais uma forma de desapropriar-se um bem; em segundo, da ofensa à Constituição Federal acerca de uma prévia indenização; em terceiro lugar, quem vai pagar o valor estabelecido? Os favelados invasores sem um nada de recursos? Foi dito e escrito que somente indagações foram encontradas e as justificativas apontam para a exclusão do Legislativo e do Executivo nestas situações, relegando delicado assunto ao arbítrio do Juiz. Ademais, encontram-se vários artigos textualizando que isto importa em nova hipótese de perda de propriedade a penalizar o proprietário que pagou os devidos impostos, impondo-lhe dano.

Por outro lado, em perfeita sintonia com o "caput", a regra do parágrafo $4^{\sharp}$ menciona imóvel reivindicado, o que induz ao requerimento do proprietário. Do dicionário atual encontramos a seguinte significação: Verbete: reivindicar [De reivindicação.] V. t. d. 1. Intentar demanda para reaver (propriedade que está na posse de outrem); vindicar. 2. Reaver, readquirir, recuperar: $\mathrm{O}$ funcionário reivindicou o antigo posto. 3. Tentar recuperar: Reivindicou em vão o lugar perdido. A justificativa inicial, na defesa do projeto, era que o juiz não determinasse 
a restituição do imóvel ao proprietário reivindicante que teve êxito na demanda, como já vimos várias vezes no noticiário televisivo: máquinas derrubando casebres e população humilde ao desabrigo. De modo diverso, que se oportunizasse ao cidadão a possibilidade de permanecer ali e indenizar, da forma mais razoável possível, o proprietário da área, que agora a perde em favor do social e não decidir sob os rigores da lei em favor de um indivíduo que acumula riquezas e deixa a área sem utilização. É bem verdade que pelo antigo "espírito" deveria ser restituído daquilo que era seu, de sua incontroversa propriedade. Aí está explicitada a razoabilidade que se diz presente no novo Código, impondo mais uma leitura ao artigo $5^{*}$ da Lei de Introdução ao Código Civil.

É bem verdade que o princípio da socialidade é um dos que norteam o novo Código e que isto não justificaria a subversão de princípios constitucionais. Entretanto, por falar neste princípio, que reforça a função social da posse e da propriedade, esta noção não é nova, uma vez que começou a despontar ainda na fase contemporânea com o advento do Constitucionalismo Social, pois até então o direito de propriedade era marcado por uma idéia de absolutismo, estabelecendo um quadro individualista e egocêntrico.

Desta noção, extrai-se que já não era mais possivel que o direito de propriedade permanecesse sob a égide eminentemente privada, razão pela qual o constitucionalismo do século XX, marcadamente democrático, apresentou contornos mais modernos acerca do direito de propriedade.

Não podemos esquecer que as idéias dos socialistas utópicos, dos marxistas e até mesmo dos anarquistas contribuíram para o desenvolvimento de tais idéias, mas seria heresia não mencioná-los: AUGUSTO COMTE, que não tinha uma obra específica, reconhecia o comprometimento do individuo com o interesse social; ROUSSEAU, que pregava a organização sob o manto de uma liberdade civil, social e comunitária; LÉN DUGUTT, SÃO BASÍLIO, SÃO TOMÁS E SANTO AGOSTINHO explicitaram a filosofia cristã e a doutrina social da Igreja, destacada inclusive por intermédio das encíclicas. Demais disto, têm-se ainda a evolução Constitucional acerca do assunto, mas várias obras já trataram brilhantemente do assunto, motivo pelo qual me furtarei de continuar discotrendo sobre isto.

Entretanto, de qualquer sorte, não devemos descuidar do fato de que - ESTATUTO DA CIDADE também trata do usucapião coletivo e impende destacar que são dois documentos da mesma época.

$O$ fato é que, apesar de que muitos afirmam que estas regras previstas 
no artigo 1.228 abalam o direito de propriedade, incentivando a invasão de glebas urbanas e rurais, exige-se para a perda, a posse ininterrupta, de boa-fé e por mais de 5 anos. Logo, é muito tempo para que alguém fique inerte nestes dias.

Mas a situação fica ainda mais complicada após a análise das disposições constantes no Estatuto da Cidade, mais precisamente no artigo $10 \mathrm{e}$ parágrafos da Lei 10.257 de julho 2001. Se de um lado o Código Civil no parágrafo $4^{2}$ trata de extensa área, o Estatuto menciona áreas com mais de duzentos e cinqüenta metros quadrados.

De qualquer forma, não comungo com o pensamento de que isto aniquila o direito de propriedade previsto na atual Carta Política, configurando um confisco, mas sim um retorno às considerações iniciais, algo movido pelo coletivo, pelo conteúdo social.

Já que mencionei o ESTATUTO DA CIDADE, nos artigos 21 a $24^{5}$ é tratado do direito de superfície, com as seguintes divergências em relação ao Código Civil: no Artigo 21: pode ser por tempo indeterminado, ao passo que o atual Código Civil, no artigo 1.369, faz menção a um tempo determinado; o Artigo 21, parágrafo $1^{2}$ : abrange o subsolo e o espaço aéreo, mas o novo Código, no artigo 1.369, explicita que em regra é só o solo.

Destarte, o operador do Direito somente dúvidas encontra ao pretender aplicar, ao caso concreto, um ou outro documento legal.

'A Lei Lei 10.257 de julho 2001, Estatuto da Cidade, na Seção VII trata do direito de superficie:

Art. 21. O proprietário urbano poderá conceder a outrem o direito de superfície do seu terreno, por tempo determinado ou indeterminado, mediante escritura pública registrada no cartório de registro de imóveis.

$\S 1$ o $O$ direito de superfície abrange o direito de utilizar o solo, o subsolo ou o espaço aéreo relativo ao terreno, na forma estabelecida no contrato respectivo, atendida a legislação urbanística.

$\S 2$ A concessão do direito de superfície poderá ser gratuita ou onerosa.

$\S 3$ O superficiário responderá integralmente pelos encargos e tributos que incidirem sobre a propricdade superficiária, arcando, ainda, proporcionalmente à sua parcela de ocupação efetiva, com os encargos e tributos sobre a área objeto da concessão do direito de superfície, salvo disposição em contrário do contrato respectivo.

$\S 4^{\circ}$ O direito de superfície pode ser transferido a terceiros, obedecidos os termos do contrato respectivo. $\S 5^{2}$ Por morte do superficiário, os seus direitos transmitem-se a seus herdeiros.

Art. 22. Em caso de alienação do terreno, ou do direito de superficie, o superficiário e o proprietário, respectivamente, terão direito de preferência, em igualdade de condições à oferta de terceiros.

Art. 23. Extingue-se o direito de superficie:

I - pelo advento do termo;

II - pelo descumprimento das obrigações contratuais assumidas pelo superficiário.

Art. 24. Extinto o direito de superficie, o proprietário recuperará o pleno domínio do terreno, bem como das acessões e benfeitorias introduzidas no imóvel, independentemente de indenização, se as partes não houverem estipulado o contrário no respectivo contrato.

$\S 1^{2}$ Antes do termo final do contrato, extinguir-se-á o direito de superfície se o superficiário der ao terreno destinação diversa daquela para a qual for concedida.

$\S 2^{\circ}$ A extinção do direito de superfície será averbada no cartório de registro de imóveis. 
Um outro aspecto relevante é no que tange às construções e plantações, pois vejarse o Parágrafo Único do artigo 1225:

Art. 1.255. Aquele que semeia, planta ou edifica em terreno alheio perde, em proveito do proprietário, as sementes, plantas e construçôes; se procedeu de boa-fé, terá direito a indenização.

Parágrafo único. Se a construção ou a plantação exceder consideravelmente o valor do terreno, aquele que, de boa-fé, plantou ou edificou, adquirirá a propriedade do solo, mediante pagamento da indenização fixada judicialmente, se não houver acordo.

Se era verdadeira a afirmação que o solo era o principal e aquilo que nele se assentasse era acessório, a regra de que o acessório segue o principal, ao menos a este particular, parece-nos que não mais se aplica.

Uma outra questão digna de menção é aquela motivada pelas exigências da vida moderna, estabelecida no artigo 1.286 , já que mediante indenizaçăo, deve-se tolerar a passagem de cabos, tubulaçōes e outros condutos subterrâneos de serviço de utilidade pública.

Um outro aspecto de enorme relevância é quanto ao capítulo que trata do condomínio edilício. É bem verdade que não encontramos esta terminologia em nossos dicionários e a despeito de que este neologismo já tenha recebido críticas, o termo tem origem latina e isto também não vai alterar muita coisa mesmo. A questão da denominação então é o menor dos problemas.

Os fundamentos destas disposições encontramos na Lei 4591/1964, que regulamenta o condomínio em plano horizontal e a crítica reside na afirmação do seguinte artigo:

Art. 1.331. Pode haver, em edificaçôes, partes que são propriedade exclusiva, e partes que são propriedade comum dos condôminos.

O melhor entendimento é que obrigatoriamente devem existir partes comuns, pois isto é da essência do condomínio. O que apresenta elementos de dificil ajuste nos casos concretos, é que o Código autoriza que uma garagem seja alienada a um estranho ao condomínio. Isto faz com que, efetivamente, deixemos de considerála como acessório e talvez a noção de pertença seja mais cabível.

O Código ainda traz um sistema punitivo ao condômino nocivo, o que na prática tem proporcionado alguns desconfortos. Não fosse somente isto, deixa algumas lacunas, e somente a título de exemplo, menciono o artigo 1.331, parágrafo 5 : que faz alusão à escritura de constituição. Ao seu 
turno, o artigo 1.332 explicita ato entre vivos ou testamento. E então, admite ou não o instrumento particular? Porque senão como o enfrentaremos à luz dos artigos 104 e 166 no que se refere à forma? Estaríamos diante de nulidade?

Um outro aspecto ainda complexo, é com relação à multa condominial, eis que diferentemente do montante até então previsto pela aludida Lei, de $20 \%$, agora explicita $2 \%$, o que conduziria a inadimplência. A influência, percebe-se, é do Código de Defesa do Consumidor, mas a natureza jurídica da relação condominial não é consumerista.

Sobeja então a pergunta do motivo pelo qual não se regulamentou os condomínios fechados que tanto proliferaram nestes últimos tempos. Seria devido à época do projeto? Talvez este não tenha sido tão atualizado assim como se anunciou.

Outro aspecto de enorme relevância é quanto ao capítulo que trata do direito de superfície. Após acabar com alguns resquícios originários da Idade Média, como a enfiteuse, o Código traz a figura deste direito. Entretanto, mais uma vez as disposições são conflitantes com o Estatuto da Cidade, pois o artigo 1.369 autoriza esta concessão, por tempo determinado, ao passo que o artigo 21 do já mencionado Estatuto autoriza-o por tempo indeterminado.

Mais do que isto, o Código, no parágrafo único do 1.369 , ainda traz a regra geral, de que não se autoriza obras no subsolo, a seu turno, o Estatuto, no artigo 21, parágrafo 1 , o estende ao subsolo ou o espaço aéreo. Fica então difícil de afirmar da aplicabilidade de uma ou outra norma no caso em concreto, mesmo sob o ponto de vista de se considerar uma norma geral e outra especial. Seria o melhor entendimento extraído a partir da noção que uma disposição legal é posterior à outra?

O Código ainda comete algumas impropriedades técnicas, como se depreende da leitura do artigo 1.313, Parágrafo $3^{2}$, ao mencionar ressarcimento, quando na verdade estaremos diante da figura da indenização. De qualquer maneira, esta não é a única, pois encontramos várias ao longo de toda obra, muito certamente fruto de uma fracionada tarefa sem o esperado trabalho de sistematização. 


\section{Conclusão}

De acordo com a nova ordem civil, percebe-se que no que tange ao instituto da posse, o Código leva em conta sua natureza social, reduzindo por isto mesmo os prazos de sua aquisição por usucapião. Assim é que, conforme o artigo 1.238, foi fixado o prazo de 15 anos para a aquisição da propriedade imóvel, independentemente de título e boa-fé, sendo esse prazo reduzido a dez anos "se o possuidor houver estabelecido no imóvel a sua moradia, ou nele realizado obras ou serviços de caráter produtivo."

Neste diapasão, por intermédio da regra constante no artigo 1.239 , bastam cinco anos ininterruptos para o possuidor, que năo seja proprietário de imóvel rural ou urbano, adquirir o domínio de área em zona rural não superior a cinqüenta hectares, tornando-a produtiva por seu trabalho ou de sua família, tendo nele sua moradia. Para tanto basta que não tenha havido oposição.

O mesmo sentido social caracteriza o artigo 1.240, segundo o qual, se alguém "possuir", como sua, área urbana até duzentos e cinqüenta metros quadrados, por cinco anos ininterruptos e sem oposição, utilizando-a para sua moradia e de sua família, adquirir-lhe-á o domínio, desde que não seja proprietário de outro imóvel."

Um magnífico exemplo da preponderância do princípio de socialidade é dado pela regra constante do artigo 1.242, segundo a qual "adquire também a propriedade do imóvel aquele que, contínua e incontestavelmente, com justo título e boa-fé, o possuir por dez anos". Esse prazo, porém, é reduzido a cinco anos se o imóvel houver sido adquirido onerosamente, com base em transcrição constante do registro próprio, cancelada posteriormente, desde que os possuidores nele tiverem estabelecido sua moradia, ou realizado investimento de interesse social e econômico, como se lê do Parágrafo Único do mesmo artigo.

Nota-se então que, ao fixar um novo paradigma, o Código Civil de 2002 optou por conceber uma linguagem aberta, utilizando-se de cláusulas gerais e conceitos jurídicos indeterminados estrategicamente colocados em seu texto. Destaque-se que esta técnica legislativa foi defendida quando da codificação do Direito Civil Alemão, motivo pelo qual aquele Código, além de ser extremamente elogiado por isto, mantém-se bastante atualizado.

Como seria tarefa dificil e fatigante anotar aqui todas as mudanças 
constantes do novo Código, inclusive por não comportar esta espécie de trabalho, optei por anotar as principais propostas de alteração desta parte do Código Civil, todas apresentadas pelo Deputado Ricardo Fiúza:

PROJETO DE LEI N*. 6.960 - PROPÕE AS SEGUINTES ALTERACOES:

"Art. 1.196. Considera-se possuidor todo aquele que tem poder fático de ingerência sócio-econômica, absoluto ou relativo, direto ou indireto, sobre determinado bem da vida, que se manifesta através do exercício ou possibilidade de exercício inerente à propriedade ou outro direito real suscetivel de posse, "

"Art. 1.197. A posse direta dos bens, mesmo que em caráter temporário e decorrente de direito pessoal ou real, não anula a posse indireta de quem foi havida, podendo, qualquer um deles agir em sua defesa, inclusive por ato praticado pelo outro possuidor.

"Art. 1.204. Adquire-se a posse de um bem quando sobre ele o adquirente obtém poderes de ingerência, inclusive pelo constituto possessório".

"Art.1.210.

$\S 2^{\text {a }}$ Se a coisa móvel ou título ao portador houverem sido furtados ou perdidos, o possuidor poderá reavê-los da pessoa que o detiver, ressalvado a esta o direito de regresso contra quem thos transferiu. Sendo o objeto comprado em leilão público, feira ou mercado, o dono, que pretender a restituição, é obrigado a pagar ao possuidor o preço pelo qual o comprou; $\S 3^{a}$ Não obsta à manutenção ou reintegração na posse a alegação de propriedade, ou de outro direito sobre a coisa".

"Art.1.228.

$\S 5^{\text {a }}$ - No caso do parágrafo antecedente, o juiz fixará a justa indenização devida ao proprietário; pago integralmente o preço, valerá a sentença como título para o registro do imóvel em nome do respectivo possuidor".

PROJETO DE LEI N ${ }^{2} .7312$ - PROPÕE A SEGUINTE ALTERAÇÃO: "Art.1.242.

Parágrafo único. Será de cinco anos o prazo previsto neste artigo se o imóvel houver sido adquirido, onerosamente, com base no registro constante do respectivo cartório, cancelada posteriormente, desde que os possuidores nele tiverem estabelecido a sua moradia, ou realizado investimentos de interesse social e econômico".

PROJETO DE LEI N ${ }^{3} .6960$-PROPÕE AS SEGUINTES ALTERAÇÕES: 
"Art. 1.274. Se da união de matérias de natureza diversa se formar espécie nova, à confusão, comistão ou adjunção aplicam-se as normas dos arts. 1.270 e 1.271 ”.

"Art.1.276

$\S 2^{a}$ Presumir-se-á a intenção a que se refere este artigo, quando, cessados os atos de posse, deixar o proprietário de satisfazer os ônus fiscais ".

"Art.1.316.

$\S 3^{\text {a }}$ A renúncia prevista no caput deste artigo poderá ser prévia e reciprocamente outorgada entre os condôminos quando da celebração do acordo que tornar indivisa a coisa comum".

"Art.1341

$\S 1^{\text {a }}$ As obras ou reparaçóes necessárias, que não ultrapassem o orçamento aprovado em assembléia, podem ser realizadas, independentemente de autorização, pelo síndico, ou, em caso de omissão ou impedimento deste, por qualquer condômino.

$\S 2^{\text {a }}$ Se as obras ou reparos necessários forem urgentes e seu valor ultrapassar o orçamento aprovado em assembléia, sendo necessário um rateio extra ou saque do Fundo de Reserva, ou de qualquer outro Fundo, determinada sua realização, o síndico ou condômino que tomou a iniciativa deverá convocar imediatamente uma assembléia, a fim de que os moradores tenham ciência do ocorrido e do valor da obra. Caso tenha se optado pelo saque do Fundo, os moradores deliberarão se o valor será reposto com um rateio extra ou mensalmente com o próprio valor arrecadado no boleto do condomínio.

"Art. 1.347. A assembléia escolherá um síndico, que poderá não ser condômino, para administrar o condomínio, por prazo não superior a dois anos, o qual poderá renovar-se por um único período consecutivo".

"Art.1.352.

$\$ 2^{2}$ No caso de um mesmo condômino possuir mais de uma unidade ou fração ideal, seu dircito de voto será limitado à soma dos votos dos demais co-proprietários, cabendo ao presidente da mesa, em caso de empate, o voto de desempate ". (NR)

"Art.1.354.

Parágrafo único. Os condôminos poderão se fazer representar por procuração, sendo vedada a outorga de mais de três mandatos à mesma pessoa". 


\section{ARTIGO COM DUAS PROPOSTAS DE ALTERAÇÃO:}

PROJETO DE LEI Nª. 6.960 - PROPÕE A SEGUINTE ALTERACÃO: "Art.1.361

$\$ 1^{\text {a }}$ Constitui-se a propriedade fiduciária com o registro do contrato, celebrado por instrumento público ou particular, que lhe serve de título, no Registro de Títulos e Documentos do domicílio do devedor, e, em se tratando de veículos, na repartição competente para o licenciamento, fazendo-se a anotação no certificado de registro;

$\S 3^{\mathrm{a}}$ A propriedade superveniente, adquirida pelo devedor, torna eficaz a transferência da propriedade fiduciária ".

PROJETO DE LEI NNa 7.312 - PROPÕE A SEGUINTE AITERAÇÃO:

"Art.1.361.

$\S 1^{\text {a }}$ Constitui-se a propriedade fiduciária com o registro do contrato, celebrado por instrumento público ou particular, que lhe serve de título, no Registro de Títulos e Documentos do domićlio do devedor, e, em se tratando de veículos, far-se-á, também, a anotação no certificado de registro, pela repartição competente para o licenciamento.

PROJETO DE LEIN N.6.960-PROPÕE AS SEGUINTES ALTERACOOEES:

"Art.1.362

I - O valor do bem alienado, o valor total da divida ou sua estimativa;

"Art.1.365

Parágrafo único. $O$ devedor pode, com a anuência do proprietário fiduciário, ceder a terceiro a sua posição no pólo passivo do contrato de alienação ".

"Art. 1.369. O proprietário pode conceder a outrem o direito de construir ou de plantar em seu terreno ou o direito de executar benfeitorias em sua edificação, por tempo determinado, mediante escritura pública devidamente registrada no cartório de Registro de Imóveis.

Parágrafo único. $O$ direito de superficie abrange o direito de utilizar o imóvel pronto ou em fase de construção, o solo, o subsolo ou o espaço aéreo relativo ao mesmo, na forma estabelecida no contrato, atendida a legislação urbanística".

"Art. 1.371. O superficiário responderá integralmente pelos encargos e tributos que incidirem sobre a propriedade superficiária, arcando, ainda, proporcionalmente à sua parcela de ocupação efetiva, com os encargos e tributos sobre a área objeto da concessão do direito de superfície, salvo disposição em contrário do contrato respectivo".

"Art. 1.374. Antes do termo final, resolver-se-á a concessão se o superficiário der ao terreno destinação diversa daquela para que foi concedida bem como se descumprir qualquer outra obrigação assumida no contrato". 
"Art. 1.379. Se, em um dos imóveis do mesmo proprietário, houver sinal exterior que revele serventia de um em favor do outro em caráter permanente, a serventia assumirá a natureza de servidão no momento em que os imóveis passarem a ter donos diversos, salvo declaração em contrário no título de transferência do domínio do imóvel alienado primeiramente.

$\$ 1$ a Aplicar-se-á o disposto neste artigo quando dois imóveis pertencentes a donos diversos resultarem de desmembramento de um imóvel único do mesmo proprietário anterior, que neste estabelecera serventia visível, por meio da qual uma de suas partes prestava determinada utilidade à outra, em caráter permanente, salvo declaração em contrário no título de transferência da parte que primeiramente for alienada.

$\$ 2^{\text {a }}$ Não se aplicará o disposto neste artigo quando a utilidade prestada pela serventia consistir numa necessidade cujo atendimento pode ser exigido por meio de um direito decorrente da vizinhança predial, caso em que o exercício de tal direito não obrigará o seu titular ao pagamento de nenhuma indenização pela utilização da serventia ".

"Art. 1.434. O credor não pode ser constrangido a devolver a coisa empenhada, ou uma parte dela, antes de ser integralmente pago".

"Art.1.436

$V$-dando-se a adjudicação judicial, a remição ou a venda da coisa empenhada, feita pelo credor ou por ele autorizada.

"Art.1.456.

Parágrafo único. O critério de preferência entre os credores de que trata o caput deste artigo será determinado pela antecedência do registro do instrumento público ou particular de penhor de direito no Registro de Títulos e Documentos do domicílio do devedor pignoratício".

"Art. 1.457. O titular do crédito empenhado só pode receber o pagamento com a anuência, por escrito, do credor pignoratício, caso em que o penhor se extinguirá, salvo disposição contratual em contrário".

"Art.1.473.

VIII - o direito de superficie"

"Art.1.479.

Parágrafo único. O compromissário vendedor de imóvel hipotecário, ainda que conste junto ao credor como devedor e principal pagador também poderá exonerar-se da hipoteca, abandonando o imóvel ao credor hipotecário, desde que o compromissário comprador tenha assumido a obrigação de liquidar o saldo devedor na forma originalmente pactuada entre o compromissário vendedor e o credor hipotecário". 
"Art.1.481

$\S 2^{\text {a }}$ Não impugnado pelo credor, o preço da aquisição ou o preço proposto pelo adquirente, haver-se-á por definitivamente fixado para a remição do imóvel, que ficará livre de hipoteca, uma vez pago ou depositado o preço.

Como se percebe, a despeito de termos um novo Código Civil, não faltam propostas para sua alteração. Isto não o diminui, pois algo muito parecido aconteceu com o revogado Código de 1916. Certamente é efeito reflexo do enorme lapso de tempo entre a apresentação do projeto e sua aprovação. Mesmo que se anuncie a extensa tarefa revisora, é cediço que sua discussão foi em muito diminuída se compararmos com o exemplo da vigente Constituição Federal. As justificativas de que não seria possível àquela época promover estes "ajustes", por problemas regimentais não poderiam prosperar. Penso mesmo que a pressa em aprovar o projeto foi tanta que estas impropriedades não foram corrigidas por falta de interesse em oportunizar uma maior discussão.

Devo salientar que optei por não fazer conclusôes pelos seguintes motivos: de um lado, ainda parece-me extremamente cedo para isto, aliado ao fato que em Direito, muitas certezas são efêmeras e somente o tempo se encarregará de apresentar as conclusões. De outro vértice, devo confessar que o objetivo nuclear era simplesmente provocar a discussão e despertar no leitor o interesse por este Livro do Código Civil, o referente ao Direito das Coisas, que pouco mudou se compararmos com os demais.

\section{BIBLIOGRAFIA}

DANTAS, Santiago. Programa de Direito Civil III. $3^{\circ}$ ed. Direito das Coisas. Revisões do texto e anotações de Gomes de Bezerra Câmara. Atualização de Laerson Mauro. Rio de Janeiro: Editora Rio, 1984.

GAMBARO. Antonio. La proprietà. Bem, proprietà, comunione. Dott. A. Giuffrè Editore. Milano.

MAZEAUD, Henri. Derechos reales principales: el derecho de propriedad y sus desmembraciones. Trad. De Luis Alcala-Zamora y Castilho. Ediciones Juridicas Europa- America. Buenos Aires, 1969.

ORRUTEA, Rogério Moreira. Da propriedade e sua função social no Direito Constitucional moderno. Editora UEL : Londrina, 1998. 